\title{
Introgression of Novel Alleles for Partial Resistance to Big Vein Disease from Lactuca virosa into Cultivated Lettuce
}

\author{
Ryan J. Hayes ${ }^{1}$ and Edward J. Ryder \\ United States Department of Agriculture, Agricultural Research Service, \\ Crop Improvement and Protection Unit, 1636 E. Alisal Street, Salinas, CA \\ 93905
}

Additional index words. Lactuca sativa, Lactuca virosa, breeding, Olpidium brassicae (Woronin) P.A. Dang, Mirafiori Lettuce Big Vein Virus, Lettuce Big Vein-associated Virus

\begin{abstract}
Big vein is an economically damaging disease of lettuce (Lactuca sativa $\mathbf{L}$.) incited by Mirafiori lettuce big vein virus, which is vectored by the soil-borne fungus Olpidium brassicae (Woronin) P.A. Dang. Resistance to this disease is needed because no feasible cultural control methods have been identified. Partial resistance is available within cultivated lettuce and is expressed as delayed appearance of symptoms in combination with a reduced percentage of symptomatic plants. Complete resistance has been identified only in accessions of $L$. virosa $L$., an incongruent wild relative of lettuce. Resistance from $L$. virosa has not been introgressed into lettuce. The objective of this research was to determine whether big vein resistance from $L$. virosa can be introgressed into lettuce. Progenies of backcross (BC) hybrids between $L$. virosa and L. sativa cultivars were greenhouse tested for big vein resistance over four generations of self-pollination. Selected plants from resistant $\mathrm{BC}$ families were used as parents to create $\mathrm{BC}_{2}$ progeny from crosses with high partial-resistant cultivars, intermediate partialresistant cultivars, and susceptible cultivars to test for the presence of transgressive segregants. Experiments were conducted in the greenhouse by infecting seedlings with $O$. brassicae zoospores collected from big vein symptomatic plants. Plots were evaluated for area under the disease progress curve and the percentage of symptomatic plants; asymptomatic plants from resistant families were retained in every generation. Complete resistance to big vein was not recovered, and may be the result of insufficient sampling of $\mathrm{BCF}_{2}$ progeny or linkage between resistance alleles and alleles causing incongruity. Variation for partial resistance was observed in all $\mathrm{BC}$ generations, and transgressive segregants were identified among $\mathrm{BC}_{2}$ families from crosses using partially resistant and susceptible parents. This research suggests that $L$. virosa contains alleles that confer partial resistance to big vein when introgressed into an $L$. sativa background, and these alleles are distinct from those present in partially resistant lettuce cultivars. Alternative breeding strategies should be pursued to introgress complete resistance from $L$. virosa into cultivated lettuce.
\end{abstract}

Big vein is an economically damaging disease of lettuce (Lactuca sativa L.). Symptoms include chlorosis surrounding the vascular bundles and leaf stiffening that can disrupt normal head development, resulting in a reduced frequency of marketable heads. Big vein is caused by a virus, vectored by the soil-borne fungus Olpidium brassicae (Woronin) P.A. Dang (Jagger and Chandler, 1934). The disease-causing virus is reported to be Mirafiori Lettuce Big Vein Virus (MLBVV) (Lot et al., 2002; Roggero et al., 2003a). Big vein is most prevalent in cool wet soils (Campbell and Grogan, 1963; Westerlund et al., 1978a, b), and increases with continuous lettuce production without rotation. Consequently, big vein consistently

Received for publication 18 July 2006. Accepted for publication 7 Sept. 2006.

${ }^{1}$ To whom reprint requests should be addressed; e-mail rhayes@pw.ars.usda.gov occurs at high levels during spring production in California's coastal growing districts, and during winter production in Arizona.

Controlling big vein is important for sustaining production of quality lettuce in California and Arizona, where $99 \%$ of U.S. lettuce production occurs (Anonymous, cultural control are currently available. Therefore, effective long-term control of genetic resistance. Within cultivated lettuce, partially resistant cultivars are available that have a reduced frequency of symptomatic plants or symptom expression that is delayed until plants reach market maturity (Ryder and Robinson, 1995). Cultivars with this type of resistance have improved marketable yields in fields infested with big vein (Ryder 1979). However, progress in increasing the level of partial resistance or the development of complete resistance has been slow. Wild Lactuca species represent an important 2006). No economically viable methods of big vein disease is best accomplished through source of useful alleles that could be used to achieve higher levels of resistance to big vein. Among the wild relatives of lettuce, complete resistance to big vein has only been identified in accessions of L. virosa L. (Bos and Huijberts, 1990; Hayes et al., 2006), but this resistance has not been introgressed into lettuce cultivars. Although L. sativa and $L$. virosa are both $2 \mathrm{n}=2 \mathrm{x}=18$, introgression of $L$. virosa genes is complicated by extreme sterility in the hybrid progeny. L. virosa is evolutionarily divergent from $L$. sativa (Koopman et al., 1998, 2001), and introgression has required bridge crosses with L. serriola, colchicine doubling, or embryo rescue (Eenink et al., 1982; Maisonneuve et al., 1995; Thompson and Ryder, 1961). The objective of this research was to determine whether big vein resistance from $L$. virosa can be introgressed into cultivated lettuce.

\section{Materials and Methods}

Backcross $(\mathrm{BC})$ L. virosa $\times$ L. sativa hybrids generated from embryo rescue were provided by B. Maisonneuve (INRA, Montfavet, France) for these experiments. The term backcross in this report refers only to crossing $L$. virosa $\times L$. sativa hybrid plants of any generation of self-pollination back to any $L$. sativa genotype. The $L$. sativa parent used to create the original interspecific $\mathrm{F}_{1}$ was not necessarily used in subsequent crosses. The L. virosa parent was from accession IVT280, which was reported to be completely resistant to big vein (Bos and Huijberts, 1990; Hayes et al., 2006). The L. sativa parents used in crosses to IVT280 and to create the BC generation were the butterhead cultivars Girelle, Melina, and Galore, and the red oak leaf cultivar Cocarde. Every effort was made to include these parents in all tests; however, some experiments did not include a complete set of parents because of limited seed quantity. Starting with 13 unselected $\mathrm{BCF}_{2}$ families, selection for big vein resistance was conducted through four generations from selfpollination (Table 1). Selection was practiced by retaining seed from the asymptomatic plants of resistant families. The seed from each plant was maintained separately. An exception was made when saving seed from $\mathrm{BCF}_{2: 3}$ plants; seed from all plants within each selected family was massed to create a $\mathrm{BCF}_{2: 4}$ generation. Different numbers of replications and control cultivars were used in evaluations of each $\mathrm{BC}$ generation. The $\mathrm{BCF}_{2}$ generation was tested in an unreplicated greenhouse trial with recurrent parents and the high partial-resistant (HPR) cultivar Pavane (Latin) and the susceptible cultivar Great Lakes 65 (iceberg). The $\mathrm{BCF}_{2: 3}$ families were evaluated with their parents and three replications of 'Pavane' and 'Great Lakes 65'. The $\mathrm{BCF}_{2: 4}$ generation was tested along with 'Pavane', the HPR cultivar Pacific (iceberg), and 'Great Lakes 65', all having two replications. The $\mathrm{BCF}_{4: 5}$ lines were tested with three replications along with their parents, 'Pavane', 'Great Lakes 65', and the HPR cultivar Margarita (butterhead). Based 
Table 1. Generation, breeding activity, the number tested, and the number retained during selection for big vein resistance in backcross $(\mathrm{BC})$ and $\mathrm{BC}_{2} L$. virosa $\times$ L. sativa progeny.

\begin{tabular}{|c|c|c|c|}
\hline Generation & Breeding activity & No. tested & No. retained \\
\hline & Selection within BC progeny & & \\
\hline $\mathrm{BCF}_{2}$ & Inoculate and select for resistance & 13 families & 81 plants from 5 families \\
\hline $\mathrm{BCF}_{2: 3}$ & Inoculate and select for resistance & 81 families & 31 families \\
\hline $\mathrm{BCF}_{2: 4}$ & Inoculate and select for resistance & 31 families & 21 plants from 5 families \\
\hline $\mathrm{BCF}_{4: 5}$ & Inoculate and select for resistance & 21 families & NA \\
\hline $\mathrm{BC}_{2} \mathrm{~F}_{1}$ & $\begin{array}{l}\text { Development and selection within } \mathrm{BC}_{2} \\
\text { Cross selected BC parents to high partial-resistant, intermediate partial- } \\
\text { resistant, and susceptible } L \text {. sativa cultivars }\end{array}$ & NA & NA \\
\hline $\mathrm{BC}_{2} \mathrm{~F}_{2}$ & Randomly select plants for seed increase & NA & 183 plants from 5 families \\
\hline $\mathrm{BC}_{2} \mathrm{~F}_{2: 3}$ & Inoculate and select putative transgressive segregants & 183 families & 212 plants from 65 families \\
\hline $\mathrm{BC}_{2} \mathrm{~F}_{3: 4}$ & Inoculate and confirm transgressive segregants & 212 families & NA \\
\hline
\end{tabular}

NA, Not applicable.

on the results from evaluating $\mathrm{BC}$ progeny, $\mathrm{BC}_{2}$ families from crosses with two $\mathrm{BC} L$. virosa $\times$ L. sativa hybrid breeding lines were generated for further testing (Table 1). Asymptomatic plants from $\mathrm{BCF}_{2: 3} \mathrm{HPR}$ family 00-366-3 were crossed to susceptible 'Salinas $88^{\prime}$ and the HPR cultivars Pacific and Pavane. Asymptomatic plants from the intermediate partial-resistant (IPR) family 00 366-9 was crossed to IPR cultivar Clemente (romaine) and 'Salinas 88'. A random selection of $\mathrm{BC}_{2} \mathrm{~F}_{2}$ plants were grown to seed, and the resulting $\mathrm{BC}_{2} \mathrm{~F}_{2: 3}$ families were tested in an unreplicated greenhouse trial along with L. sativa parents, 'Great Lakes 65', and IVT280 to identify putative transgressive segregants. Seed was saved from each asymptomatic plant from families identified as putative transgressive segregant families. The resulting $\mathrm{BC}_{2} \mathrm{~F}_{3: 4}$ families were divided into two equivalent sets by sampling equal numbers of lines derived from each $\mathrm{BC}_{2} \mathrm{~F}_{2: 3}$ family. Each set was then evaluated for big vein resistance in independent greenhouse experiments to confirm the existence of transgressive segregants. These experiments used three replications of each $\mathrm{BC}_{2} \mathrm{~F}_{3: 4}$ family and nine replications of 00-366-3, 00-366-9, 'Pavane', 'Pacific', 'Clemente', 'Salinas 88', and $L$. virosa accession IVT280.

All experiments were conducted using a greenhouse assay (Ryder and Robinson, 1995). Inoculum was produced in the greenhouse by growing big vein symptomatic plants in $15-\mathrm{cm}$ pots containing $O$. brassicae-infested field soil collected from the U.S. Department of Agriculture, Agricultural Research Service research station in Salinas, Calif. The field soil used to grow symptomatic plants was collected from the same location for each experiment, and reverse transcription-polymerase chain reaction of MLBVV isolates obtained from plants grown in this soil were closely related to other MLBVV isolates in California, Arizona, Europe, and Japan (Hayes et al., 2006). At the time of inoculation, a suspension of more than $30,000 O$. brassicae zoospores $/ \mathrm{mL}$ was prepared from six symptomatic plants by macerating the roots in water. Seedlings were germinated in potting mix containing 2 field soil : 1 sand and grown for 3 weeks. Inoculations were conducted by watering these seedlings with the zoospore suspension on two separate occasions, each separated by $48 \mathrm{~h}$. Twelve seedlings per plot were subsequently transplanted into $8-\mathrm{cm}$ pots containing field soil, except in experiments with $\mathrm{BC}_{2} \mathrm{~F}_{3: 4}$ families in which eight seedlings were transplanted per plot. Plants were grown in a greenhouse maintained at $18{ }^{\circ} \mathrm{C}$, and the proportion of plants per plot with leaf vein banding typical of big vein disease was recorded every $7 \mathrm{~d}$ for up to 8 weeks and was used to calculate the area under the disease progress curve (AUDPC).

Data were analyzed using the PROC Mixed procedure of SAS (2004, version 9.1) with entries (families, control cultivars, parents, and accessions) as a fixed effect and replications as random effects. In experiments in which hybrid families were not replicated, replication of control cultivars and parents was used to estimate the error needed for significance testing. The data from evaluations of $\mathrm{BC}_{2} \mathrm{~F}_{3: 4}$ families had skewed distributions and were analyzed using nonparametric methods. For comparison among parents and among pedigrees, the median AUDPC was calculated for each parent and for each pedigree. The range AUDPC (range $=$ maximum AUDPC - minimum AUDPC) was also calculated for the families within each pedigree to estimate the amount of variation. To identify transgressive segregants, the data were analyzed using analysis of variance-type statistics of ranked data using the PROC Mixed procedure in SAS (2004, version 9.1) (Brunner et al., 2002; Shah and Madden, 2004). The relative marginal effects (RME), a value ranging from 0 to 1 , were calculated as the mean rank divided by the number of plots (experimental subjects). The LD_CI macro was used in Proc Mixed to calculate the RME and $95 \%$ confidence intervals of RME for detection of statistical difference among entries. To control for increased type 1 error associated with multiple testing, the confidence interval used an alpha of 0.05 divided by the number of statistical comparisons within each pedigree. These comparisons were made only after significant differences were identified by Proc Mixed. The analysis was conducted separately for each experiment, where entries (families, parents, and accession) were fixed effects and replications were random effects. Transgressive segregants were identified as $\mathrm{BC}_{2} \mathrm{~F}_{3: 4}$ families that were significantly more resistant than both parents. The percentage of transgressive segregants was calculated for each pedigree.

\section{Results}

Greenhouse evaluation of unselected $\mathrm{BCF}_{2}$ families identified variation among families for resistance to big vein, with percent symptomatic plants ranging from $9 \%$ to $80 \%$ (data not shown). No families with complete resistance, as seen in L. virosa accession IVT280, were observed. Twentyfive percent of the families had fewer symptomatic plants than the HPR control cultivar Pavane (17\% symptomatic), and $83 \%$ percent of the families had fewer symptomatic plants then the susceptible control 'Great Lakes 65' (42\% symptomatic plants). The three recurrent parents tested - 'Girelle', 'Milena', and 'Cocarde'-were all more susceptible than 'Great Lakes 65'.

Variation for AUDPC and percent symptomatic plants was identified in $81 \mathrm{BCF}_{2: 3}$ families previously selected for partial resistance (Fig. 1). The AUDPC of families ranged from 1.3 to 76.1 , and $88 \%$ of the families were not significantly different from 'Pavane' (Fig. 1). L. virosa accession IVT280 had no symptomatic plants (Fig. 1). The recurrent parents in this experiment all had more than $83 \%$ symptomatic plants and AUDPC values more than 53.5 (Fig. 1). Considering just the families derived from 00-366, it is apparent that many $\mathrm{BCF}_{2: 3}$ families derived from this $\mathrm{BCF}_{2}$ family have a high level of partial resistance to big vein. None of these families were significantly different from 'Pavane', and four of five families with lower AUDPCs than 'Pavane' were all derived from 00-366 (Fig. 1). Furthermore, the best-performing family (00-366-3) was derived from $\mathrm{BCF}_{2}$ family $00-366$. Family $00-366$ was produced from the cross (IVT280 $\times$ 'Cocarde') $\times$ 'Galore', and in this experiment 00-366-3 was significantly more resistant than the parent cultivar Cocarde (Fig. 1). The susceptible parent 'Galore' was not included in this experiment.

The AUDPCs in the $\mathrm{BCF}_{2: 4}$ generation ranged from 2.3 to 39.5 (data not shown). Although the differences in the AUDPC were not significant for this experiment, the most resistant family (02-2367) was created from a mass seed lot of asymptomatic plants from 00-366-3. Despite the lack of significant differences in the $\mathrm{BCF}_{2: 4}$ generation, 21 $\mathrm{BCF}_{2: 4}$ plants were selected from the five best-performing families for further testing in 


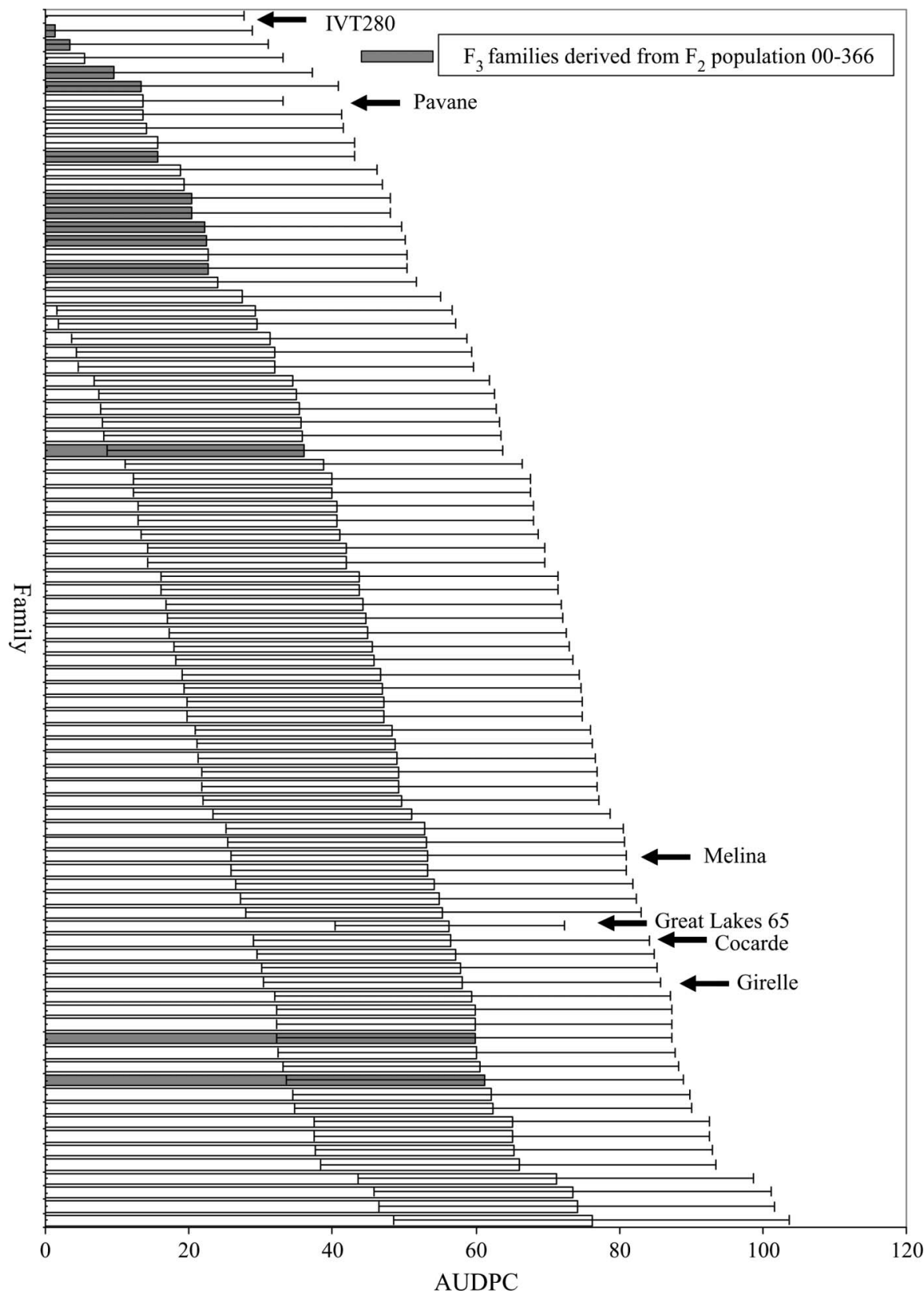

Fig. 1. Variation for big vein area under the disease progress curve (AUDPC) for $81 \mathrm{BCF}_{2: 3} L$. viros $a \times L$. sativa hybrid families; $L$. virosa parent accession IVT280; $L$. sativa parent cultivars Melina, Cocarde, and Girelle; and the L. sativa control cultivars Pavane and Great Lakes 65 in a greenhouse experiment. Error bars indicate $95 \%$ confidence intervals.

the $\mathrm{BCF}_{4: 5}$ generation. Of the $\mathrm{BCF}_{4: 5}$ families tested, family $02-2367-1$, a family descended from 00-366-3, had the lowest AUDPC in the experiment (Table 2). Other families derived from $00-366-3$ also performed well in this experiment. This includes families $02-2367-2$ and -4 , which had the lowest and second lowest percentage of symptomatic plants (Table 2). The AUDPC of every line derived from 02-2367 was significantly lower than 'Galore', one of this family's L. sativa parents (Table 2). Other lines that can be traced back to $\mathrm{BCF}_{2}$ family 00-366 also had low levels of disease. This includes the second best-performing family for AUDPC, family 02-2371-4, which is a derivative from 00-366-9 (Table 2).
Variation for AUDPC and the percentage of symptomatic plants was detected among $\mathrm{BC}_{2} \mathrm{~F}_{2: 3}$ families that have $00-366-3$ and 00-366-9 as parents (data not shown). The range of AUDPCs of these families in all pedigrees extended to zero, and included many families that had less disease than the L. sativa and $\mathrm{BC} L$. virosa $\times$ L. sativa hybrid parents (data not shown). These $\mathrm{BC}_{2} \mathrm{~F}_{2: 3}$ families were considered putative transgressive segregants. The existence of transgressive segregants was confirmed in the $\mathrm{BC}_{2} \mathrm{~F}_{3: 4}$ generation (Table 3). Families from 00-366$3 \times$ 'Pavane' and 00-366-9 × 'Clemente' had transgressive segregants in both experiments (Table 3). Transgressive segregants were identified in $00-366-9 \times$ 'Salinas 88 ' only in expt. 1 and in 00-366-3 × 'Pacific' only in expt. 2 (Table 3). Variation in the percentage of transgressive segregants was observed, and appears to result from interaction between the parent genotypes and experiment. There does not appear to be a relationship between the percentage of transgressive segregants and a pedigree's median AUDPC or family range. Rather, the percentage of transgressive segregants is more closely related to the amount of disease in the parents with which the $\mathrm{BC}_{2} \mathrm{~F}_{3: 4}$ families were compared. For example, identification of transgressive segregants in expt. 2 in $00-366-3 \times$ 'Pacific' and not in expt. 1 is likely the result of higher amounts of big vein disease in 'Pacific' in expt. 2. No transgressive segregants were found in 00-366-9 × 'Salinas 88', and lower percentages were found in 00-366-9 $\times$ 'Clemente' in expt. 2. This can be explained by a far reduced amount of disease in 00-366-9 in expt. 2 . Regardless, it seems likely that transgressive segregants are present in these populations, and suggests that the L. sativa parents and the $L$. virosa $\times L$. sativa hybrid parents differ in alleles for partial resistance to big vein.

\section{Discussion}

Big vein is an economically damaging disease of lettuce with limited options for cultural control. Consequently, resistant cultivars are the best approach to reduce the damage resulting from this disease. Partial resistance is available within cultivated lettuce and has been described as a reduction in the number of symptomatic plants or a delay in symptom expression sufficiently past market maturity to reduce economic loss (Ryder and Robinson, 1995). Field and greenhouse testing methods have been developed to select for this form of resistance (Ryder and Robinson, 1995), and cultivars with HPR have been released (Ryder and Robinson, 1995). Although complete resistance from $L$. virosa was not recovered in hybrid progeny, high levels of partial resistance were identified in $L$. virosa $\times$ L. sativa hybrids. Line 00-366-3 had the least amount of disease in the $\mathrm{BCF}_{2: 3}$ generation, and gave rise to $\mathrm{BCF}_{2: 4}$ family 02-2367 and $\mathrm{BCF}_{4: 5}$ lines 02-2367-1,-2, and -4 , which had the least amount of disease or were among the lines with the least amount of disease in their generation. Clearly, 00-366-3 has a high level of partial resistance to big vein. When 00-366-3 was used as a parent in crosses to HPR $L$. sativa cultivars, families significantly more resistant than both parents were identified. Because the resistant $L$. virosa $\times$ L. sativa hybrid parent used in this cross was developed by backcrossing into susceptible cultivars, the apparent existence of transgressive segregants in crosses to HPR $L$. sativa strongly suggests that $L$. virosa contributed unique alleles that confer partial resistance to big vein. The breeding line 00-366-9 does not appear to be as resistant as 00-366-3, but families that were significantly more resistant than 00-366-9, 'Clemente', and 'Salinas 88' were identified. This indicates that other families derived from 00-366 may be useful for 
Table 2. Big vein area under the disease progress curve (AUDPC) and percent symptomatic plants in $\mathrm{BC}_{2} \mathrm{~F}_{4: 5}$ L. virosa $\times$ L. sativa hybrids and cultivars Pavane, Margarita, and Great Lakes 65 .

\begin{tabular}{|c|c|c|c|c|c|}
\hline \multirow[b]{3}{*}{ Line } & \multirow[b]{3}{*}{ No. of plants tested } & \multirow[b]{3}{*}{ Percent symptomatic plants } & \multicolumn{3}{|c|}{ AUDPC } \\
\hline & & & \multirow[b]{2}{*}{ Mean } & \multicolumn{2}{|c|}{$95 \% \mathrm{CI}$} \\
\hline & & & & Lower & $\overline{\text { Upper }}$ \\
\hline$\overline{02-2367-1}$ & 34 & 50 & 3.9 & 0.0 & 9.9 \\
\hline Pavane & 70 & 33 & 3.9 & 0.0 & 8.3 \\
\hline $02-2371-4$ & 32 & 50 & 4.5 & 0.0 & 10.6 \\
\hline $02-2377-1$ & 27 & 37 & 4.7 & 0.0 & 10.8 \\
\hline $02-2367-2$ & 34 & 27 & 4.8 & 0.0 & 10.9 \\
\hline $02-2367-4$ & 35 & 32 & 5.4 & 0.0 & 11.5 \\
\hline $02-2371-5$ & 36 & 64 & 6.8 & 0.7 & 12.9 \\
\hline $02-2377-3$ & 34 & 44 & 7.2 & 2.0 & 12.5 \\
\hline $02-2385-5$ & 12 & 33 & 7.3 & 0.0 & 17.9 \\
\hline $02-2377-2$ & 36 & 50 & 7.7 & 1.6 & 13.8 \\
\hline $02-2367-3$ & 35 & 49 & 7.8 & 1.7 & 13.9 \\
\hline $02-2376-1$ & 34 & 41 & 8.4 & 2.4 & 14.5 \\
\hline $02-2376-4$ & 35 & 57 & 8.6 & 2.5 & 14.7 \\
\hline $02-2385-3$ & 2 & 50 & 8.8 & 0.0 & 19.3 \\
\hline Margarita & 58 & 47 & 9.0 & 4.7 & 13.3 \\
\hline $02-2366-2$ & 34 & 44 & 9.2 & 3.1 & 15.3 \\
\hline $02-2366-5$ & 34 & 44 & 9.7 & 3.6 & 15.8 \\
\hline $02-2371-2$ & 36 & 50 & 9.8 & 3.7 & 15.9 \\
\hline $02-2366-1$ & 34 & 44 & 11.2 & 5.1 & 17.3 \\
\hline $02-2377-4$ & 9 & 67 & 11.7 & 1.1 & 22.2 \\
\hline $02-2366-4$ & 33 & 58 & 12.1 & 6.0 & 18.2 \\
\hline $02-2376-2$ & 22 & 64 & 12.3 & 4.9 & 19.8 \\
\hline $02-2366-3$ & 36 & 61 & 14.5 & 8.4 & 20.6 \\
\hline $02-2371-6$ & 11 & 54 & 15.6 & 5.0 & 26.2 \\
\hline $02-2376-3$ & 12 & 75 & 19.0 & 8.4 & 29.5 \\
\hline Great Lakes 65 & 72 & 76 & 20.5 & 16.2 & 24.8 \\
\hline Ravel & 11 & 91 & 21.6 & 11.1 & 32.2 \\
\hline $02-2371-1$ & 34 & 71 & 22.9 & 16.8 & 29.0 \\
\hline $02-2371-3$ & 12 & 75 & 29.8 & 19.2 & 40.3 \\
\hline Galore & 12 & 83 & 33.8 & 23.3 & 44.4 \\
\hline $02-2368-1$ & 2 & 100 & 38.5 & 27.9 & 49.1 \\
\hline
\end{tabular}

$\mathrm{CI}$, confidence interval.

big vein resistance breeding. Furthermore, numerous $\mathrm{BC}$ families with distinct pedigrees were selected through four generations of selfpollination, but were not used to generate $\mathrm{BC}_{2}$ progeny because their level of partial resistance was not as great as 00-366-3. Although the fact that they were more susceptible than 00-366-3 further substantiates the value of $00-366-3$, it is likely that several BC lines in addition to 00-366-3 have useful big vein resistance alleles derived from $L$. virosa.

Low frequencies of $\mathrm{BC}_{2} \mathrm{~F}_{3: 4}$ families were identified as transgressive segregants, which were defined as families significantly more resistant than both parents. However, higher numbers of transgressive segregants may exist in the $\mathrm{BC}_{2} \mathrm{~F}_{3: 4}$ populations than were identified using this method. The greenhouse screen used in this research is intended to detect variation for delayed symptom expression or reduced frequency of symptom expression and, to accomplish this, does not maximize disease pressure. The lack of sufficiently high levels of big vein disease pressure may have inhibited our ability to maximize genetic variation, and reduced our ability to detect statistical differences in populations in which parents and families have low levels of disease resulting from high levels of resistance. The $\mathrm{BC}_{2} \mathrm{~F}_{3: 4}$ generation had highly skewed distributions, and it is likely that more genetic variation is available at the resistant end of the distribution. It is possible that more transgressive segregants would be identified if this variation could be exposed. New screens with higher levels of disease pressure are needed, and could be developed by increasing $O$. brassicae concentrations, increasing the duration of $O$. brassicae exposure, and using environments more conducive for virus infection and symptom expression.

The hybrid breeding lines developed in this research will likely be useful for breeding new cultivars with partial resistance to big vein. Current crisphead cultivars that are grown in California and have partial big vein resistance are closely related, and introgression of novel alleles for partial resistance to big vein can be used to increase the current level of resistance. Furthermore, the lettuce industry desires cultivars that combine big vein resistance, high yield, and freedom from physiological defects. In this regard, the $\mathrm{BC}_{2}$ families from crosses with 'Salinas 88' are particularly useful. 'Salinas 88 ' is an important parent for breeding new cultivars with high yield and quality, and numerous families with big vein resistance significantly better than 'Salinas 88' were identified. These families are an important resource for developing new big vein-resistant cultivars with a genetically distinct background.

Table 3. Median and range of area under the disease progress curve (AUDPC) for $\mathrm{BC}_{2} \mathrm{~F}_{3: 4} L$. virosa $\times$ L. sativa hybrids families and their parents and the percentage of transgressive segregants in two greenhouse experiments.

\begin{tabular}{|c|c|c|c|c|c|c|c|c|}
\hline \multirow[b]{3}{*}{ Entry } & \multicolumn{4}{|c|}{ Expt. 1} & \multicolumn{4}{|c|}{ Expt. 2} \\
\hline & \multirow[b]{2}{*}{$\begin{array}{c}\text { No. of } \\
\text { families tested }\end{array}$} & \multicolumn{2}{|c|}{ AUDPC } & \multirow{2}{*}{$\begin{array}{c}\text { Percent } \\
\text { transgressive } \\
\text { segregants }^{\mathrm{z}}\end{array}$} & \multirow[b]{2}{*}{$\begin{array}{c}\text { No. of } \\
\text { families tested }\end{array}$} & \multicolumn{2}{|c|}{ AUDPC } & \multirow{2}{*}{$\begin{array}{c}\text { Percent } \\
\text { transgressive } \\
\text { segregants }\end{array}$} \\
\hline & & Median & $\begin{array}{c}\text { Family } \\
\text { range }\end{array}$ & & & Median & $\begin{array}{c}\text { Family } \\
\text { range }\end{array}$ & \\
\hline \multicolumn{9}{|l|}{ Families } \\
\hline \multicolumn{9}{|l|}{ High $\times$ High } \\
\hline $03-366-3 \times$ Pavane & 29 & 6.6 & 31.0 & 4.5 & 22 & 2.5 & 13.1 & 4.5 \\
\hline $03-366-3 \times$ Pacific & 16 & 5.4 & 29.3 & 0.0 & 17 & 5.7 & 38.1 & 5.8 \\
\hline \multicolumn{9}{|l|}{ High $\times$ Susceptible } \\
\hline 03-366-3 $\times$ Salinas 88 & 12 & 4.6 & 28.4 & 0.0 & 12 & 5.5 & 16.0 & 0.0 \\
\hline Intermediate $\times$ Intermediate & & & & & & & & \\
\hline 03-366-9 × Clemente & 35 & 5.7 & 37.0 & 25.7 & 34 & 5.2 & 42.5 & 5.3 \\
\hline Intermediate $\times$ Susceptible & & & & & & & & \\
\hline $03-366-9 \times$ Salinas 88 & 18 & 11.3 & 29.8 & 11.1 & 17 & 5.3 & 24.5 & 0.0 \\
\hline \multicolumn{9}{|l|}{ Parents } \\
\hline IVT280 & & 0.0 & & & & 0.0 & & \\
\hline $00-366-3$ & & 7.0 & & & & 7.9 & & \\
\hline Pavane & & 6.0 & & & & 11.8 & & \\
\hline Pacific & & 4.8 & & & & 10.1 & & \\
\hline Clemente & & 9.3 & & & & 15.3 & & \\
\hline $00-366-9$ & & 11.4 & & & & 1.3 & & \\
\hline Salinas 88 & & 22.3 & & & & 23.9 & & \\
\hline
\end{tabular}

${ }^{\mathrm{z}}$ Transgressive segregants were detected as families significantly different from both parents using the $95 \%$ confidence interval of the relative marginal effect. 
Developing immunity to big vein is an important goal for resistance breeding, because this type of resistance can eliminate inoculum increases while decreasing economic loss. Immunity from wild Lactuca species would be desirable for this reason (Hayes et al., 2006). Immunity or complete resistance was not recovered in the hybrids evaluated for this research (Fig. 1, Table 2), which may be the result of selection methods that do not identify and eliminate symptomless genotypes from the population. Recently, ELISA and DNA-based detection methods of MLBVV have become available (Hayes et al., 2006; Latham et al., 2004; Navarro et al., 2004; Roggero et al., 2003b). These methods may improve selection efficiency by identifying symptomless viruscontaining plants. However, these methods were not available when these experiments were conducted. Additionally, greenhouse testing methods that reduce the number of escapes would be valuable for selecting immune genotypes.

Many useful traits exist in L. virosa, and introgression has been conducted through recurrent backcrossing that followed bridge crosses with L. serriola, colchicine doubling, or embryo rescue (Eenink et al., 1982: Maisonneuve et al., 1995; Thompson and Ryder, 1961). Successful introgression using recurrent backcross breeding with distant wild relatives is typically limited to introgression of single genes (Haghighi and Ascher, 1988; Mejia-Jimenez et al., 1994). In contrast, efforts to introgress multigene traits frequently fail. The inheritance of big vein resistance is not known in $L$. virosa, and partial resistance in L. sativa is presumed to be oligogenic (Ryder, 1980). Although the distribution and relationship among alleles for partial resistance and genes for complete resistance in L. virosa are not known at this time, it is possible that several genes of varying effects will need to be introgressed from $L$. virosa for the recovery of complete resistance in hybrid breeding lines. If the small number of original $\mathrm{BC}$ families did not represent all genes responsible for the complete resistance of L. virosa IVT280, then genetic drift may explain why complete resistance was not recovered in hybrid progeny. Additionally, selection before evaluating for big vein resistance may have eliminated resistance alleles. Introgression may also fail because of linkage between desirable genes and genes that prevent further sexual reproduction, such as those causing death, sterility, or sexual incompatibilities (Haghighi and Ascher,
1988). All these phenotypes were observed in the $L$. virosa $\times L$. sativa hybrids used for this research and may also explain why complete resistance from $L$. virosa was not recovered. Alternative hybridization strategies such as congruity backcrossing (Haghighi and Ascher, 1988; Mejia-Jimenez et al., 1994) have been designed to break linkages between introgression barriers and desirable alleles. These approaches should be pursued to increase the number of big vein resistance genes introgressed from $L$. virosa into cultivated lettuce.

\section{Literature Cited}

Anonymous. 2006. Statistics of vegetables and melons. USDA National Agriculture Statistics Service. www.nass.usda.gov/Publications/ Ag_Statistics/agr06/index.asp. Accessed Oct. 2006.

Bos, L. and N. Huijberts. 1990. Screening for resistance to big vein disease of lettuce. Crop Prot. 9:446-452.

Brunner, E., S. Domhof, and F. Langer. 2002. Nonparametric analysis of longitudinal data in factorial experiments. Wiley, New York.

Campbell, R.N. and R.G. Grogan. 1963. Big vein virus of lettuce and its transmission by Olpidium brassicae. Phytopathology. 53:252-259.

Eenink, A., H.R. Groenwold, and F.L. Dieleman. 1982. Resistance of lettuce (Lactuca) to the leaf aphid Nasanovia ribisnigri. 1. Transfer of resistance from $L$. virosa to $L$. sativa by interspecific crosses and selection of resistant breeding lines. Euphytica. 31:291-300.

Haghighi, K.R. and P.D. Ascher. 1988. Fertile, intermediate hybrids between Phaseolus vulgaris and $P$. acutifolius from congruity backcrossing. Sex. Plant Reprod. 1:51-58

Hayes, R.J., W.M. Wintermantel, P.A. Nicely, and E.J. Ryder. 2006. Host resistance to Mirafiori lettuce big-vein virus and lettuce big-vein associated virus and virus sequence diversity and frequency in California. Plant Dis. 90: 233-239.

Jagger, I.C. and N. Chandler. 1934. Big vein, a disease of lettuce. Phytopathology. 24:1253-1256.

Koopman, W.J.M., E. Guetta, C.C.M. van de Wiel, B. Vosman, and R.G. Van den Berg. 1998 Phylogenetic relationships among Lactuca (Asteraceae) species and related genera based on ITS-1 DNA sequences. Amer. J. Bot. 85:1517-1530.

Koopman, W.J.M., M.J. Zevenbergen, and R.G. Van den Berg. 2001. Species relationships in Lactuca s.l. (Lactuceae, Atseracaea) inferred from AFLP fingerprints. Amer. J. Bot. 88:1881-1887.

Latham, L.J., R.A.C. Jones, and S.J. McKirdy. 2004. Lettuce big-vein disease: Sources, patterns of spread, and losses. Aust. J. Agr. Res. 55:125-130.
Lot, H., R.N. Campbell, S. Souche, R.G. Milne, and P. Roggero. 2002. Transmission by Olpidium brassicae of Mirafiori lettuce virus and lettuce big vein virus, and their roles in lettuce big-vein etiology. Phytopathology. 92: 288-293.

Maisonneuve, B., M.C. Chupeau, Y. Bellec, and Y. Chupeau. 1995. Sexual and somatic hybridization in the genus Lactuca. Euphytica. 85:281285.

Mejia-Jimenez, A., C. Munoz, H.J. Jacobsen, W.M. Roca, and S.P. Singh. 1994. Interspecific hybridization between common and tepary beans: Increased hybrid embryo growth, fertility, and efficiency of hybridization through recurrent and congruity backcrossing. Theor. Appl. Genet. 88:324-331.

Navarro, J.A., F. Botella, A. Maruhenda, P. Sastre, M.A. Sanchez-Pina, and V. Pallas. 2004. Comparative infection progress analysis of lettuce big-vein virus and Mirafiori lettuce virus in lettuce crops by developed molecular techniques. Phytopathology. 94:470-477.

Roggero, P., M. Ciuffo, A.M. Varia, G.P. Accotto, V. Masenga, and R.G. Milne. 2003a. An ophiovirus isolated from lettuce with big vein symptoms. Arch. Virol. 145:2629-2642.

Roggero, P., H. Lot, S. Souche, R. Lenzi, and R.G. Milne. 2003b. Occurrence of Mirafiori lettuce big vein virus and lettuce big vein virus in relation to development of big vein symptoms in lettuce crops. Eur. J. Plant Pathol. 109: 261-267.

Ryder, E.J. 1979. Effects of big vein resistance and temperature on disease incidence and percentage of plants harvested of crisphead lettuce. J. Amer. Soc. Hort. Sci. 104:665-668.

Ryder, E.J. 1980. Studies on the sources and nature of big vein resistance in lettuce and progress in breeding resistant cultivars, p. 78-85. In: Proc. Eucarpia Leafy Vegetables Group Meeting. March 11-14.

Ryder, E.J. and B.J. Robinson. 1995. Big-vein resistance in lettuce: Identifying, selecting, and testing resistant cultivars and breeding lines. J. Amer. Soc. Hort. Sci. 120:741-746.

Shah, D.A. and L.V. Madden. 2004. Nonparametric analysis of ordinal data in designed factorial experiments. Phytopathology. 94:33-43.

Thompson, R.C. and E.J. Ryder. 1961. Descriptions and pedigrees of nine varieties of lettuce. Tech. bull. no. 1244. Agricultural Research Service U.S. Department of Agriculture, Washington, D.C.

Westerlund, F.V., R.N. Campbell, and R.G. Grogan. 1978a. Effect of temperature on transmission, translocation, and persistence of the lettuce big-vein agent and big-vein symptom expression. Phytopathology. 68:921-926.

Westerlund, F.V., R.N. Campbell, R.G. Grogan, and J.M. Duniway. 1978b. Soil factors affecting the reproduction and survival of Olpidium brassicae and its transmission of big-vein agent to lettuce. Phytopathology. 68:927-935. 